\title{
THE ACCURACY ASPECTS OF PUBLICATIONS OF THE DIRECTORATE OF VOCATIONAL HIGH SCHOOL DEVELOPMENT IN PROMOTING THE EXISTENCE OF THE SECONDARY VOCATIONAL EDUCATION THROUGH MASS MEDIA
}

\author{
Samsul Hadi ${ }^{*} *$ Suyanto $^{2}$, Slamet ${ }^{2}$ \\ ${ }^{1)}$ Kemdikbud, ${ }^{2}$ Universitas Negeri Yogyakarta \\ ${ }^{1}$ Jalan Jenderal Sudirman, Jakarta Pusat 10270, Indonesia \\ 2Jl. Colombo No. 1, Depok, Sleman 55281, Yogyakarta, Indonesia \\ * Corresponding Author. Email: samsul_had1@yahoo.com
}

\begin{abstract}
This study is an evaluation research aimed at examining the accuracy of substances, media, and publication schedules on the publications conducted by the Directorate of Vocational High School Development. The purposes of this study are: (1) to get information about the strength and weakness of the publication contexts which has become the basis of deciding the substances, media and publication schedule through mass media in order to get the publication effective and efficient to reach every level of society; (2) to get detail information about the accuracy of the using of substances, media and audiences' habits in the implementation phase of the publication programs of the Directorate of Vocational High School Development through mass media. This research involved vocational high school communities as the samples, including the students, teachers and parents based on the stratified-cluster sampling technique. Meanwhile, the data analysis technique used was the descriptive statistic technique. In general, the result of this research shows that the substances of the publication are appropriate to public's expectation, while the use of mass media and its publication schedule are not yet fully appropriate to achieve accuracy.
\end{abstract}

Keywords: mass media, accuracy, publication

Permalink/DOI: http://dx.doi.org/10.21831/pep.v21i2.12522 


\section{Introduction}

Currently the government of Indonesia is giving attention to vocational education. The target is for vocational secondary education to be the solution of future skilled labor supply to take opportunities to advance Indonesia. According to the McKinsey Global Institute (2012), Indonesia has the opportunity to become the world's seventh largest economy by 2030. To achieve the opportunity, there are four main sectors take significant role including services, agriculture and fisheries, and energy. The skilled labors need at the time is about 113 million people, while in the 2012, the number of the skilled labors were only 50 millions people.

Observing the demographic trend during 2010-2035 that is likely in a demographic bonus, a condition in which the number of productive age population is greater than the non-productive age. In this condition, the opportunity to achieve such progress becomes more pronounced. This proportion enables for family to increase their purchasing including education for their own kids.

Lastariwati (2012, p. 79) stated that the vocational high schools are an integral part that can not be separated from the growth of the Indonesian economy. The problem is in the effort to make vocational education as an expectation for the provision of the skilled human resources' needs which is still barried by the lower interest of the public to participate in vocational high schools compared to the high schools for senior secondary school level. The Education Minister, Mohammad Nuh presented that the number of high school graduates that continue their study to universities is only $23 \%$, it means that $77 \%$ of the graduates terminate their education after graduated from high school, and assumed to be unemployed, or work as unskilled human resources.

Therefore, making vocational high schools to be the favorite secondary education in the future is able to reduce the number of unemployed and unskilled work- ers. The commitment does not only belong to the Directorate of Vocational High School Development, but also the business and the industrial field which spread from topstreams to buttomstreams, large to micro, in the urban areas to rurals should be the same vision to support this strategy. Business and industrial communities do not need to put vocational schools as competitor since some of them began to develop the assembly of cars, motor-cycles, laptops and even airplanes.

To meet the goal, all vocational stakeholder through-out Indonesia should understand the function of vocational school well, appreciate and support for in the real way. One of the efforts to build understanding and changing of the vocational high school image for society is publication through the mass media.

The "Publication" term comes from the "Public" word, in accordance to Indonesian Dictionary, the word means many or common people. "The public" can be declared as the direct or indirect group of interest to the organization. Therefore, publication can be defined as a process to make people interested to the organization. The formulation of this sentence is in line with the definition of publication according to Susanto \& Gusmian (2004, p. 132), publication is an act of disseminating information to influence the public.

Meanwhile, the mass media are all kinds of communication media to reach the public (La Torre \& Calzoni, 2013, p. 163). Based on the technology used, mass media are categorized into two: the electronic media and printed media (Sari, 1993, p. 25). Both media are based on the characteristics of the technology used in the transmitters' systems. Electronic media use electronic technology either analog or digital broadcast systems, while the printed media use printing technology to deliver the information. This distinction brings a different impact on (1) the distribution of the audience, (2) time in transmiting the information, (3) the information format and (4) the span length. La Torre \& Calzoni (2013, p. 163) 
states that the product of mass media are including to seven types of products, they are: books, magazines, newspapers, movies, TV, Radio and Internet.

Every kind of media has its own strengths and weaknesses. Based on the audience, the duration of the time, the display, the transmission, the range and the capacity of the message, every media is different from one to the others (Medoff \& Kaye, 2011, p. 16). According to the audiences, some media are able to delivery information to the broad society at the same time, while some of them, such as telephones can only send message to a single audience at once. The time need in this case is the time required by the media to transmite the information from the source to the receiver. The display is the information format which can be in the form of audio, video, pictures and text. The distribution refers to the means or the technology used to transmit information from the source to the receiver. The distance or range in this case refers to the covered area of the information dissemination. Storage is related to the capacity of the media in disseminating information such as optimum printed media can only stores a dozens of pages at once.

Based on the characteristics of the media, the public institutions in conducting publication can take advantage of either the printed media or electronic media depend on their needs. According to Sari (1993, p. 26), readers of printed media must have access to the media or to subscribe, besides they must have abilities and opportunities to read. That is the reason why the majority of this media audiences are the educated people. Geographically the coverage of printed media are very limited and the shortest publishing priod is once a day, so the actuality of the information is relatively low. However, "The print media are proved as the most effective, especially in the quality of communication, because the reader can receive information clearly" (Sari, 1993). One of the publication format that can be done through the printed media are opinions or articles containing ideas, re- views, or criticism of an existing problems in the community with a popular scientific language (Bahar, 2008, p. 114). For the purpose of the policy publication, an opinion article is written in the popular scientific by 'the expert who allege the expert position toward an issue or policy that begins with an analysis of the positive and negative sides of the policy in which the conclusion support the policy. Another kind is advertorial in which the simple definition is the writing to promote or support a policy placed on the pages of the policy context (Brown, 2006, p. 54). The others defined advertisement as a posts containing simple messages intended to influence audiences (Veerkumar, 2015, p. 24). The last way to make publication in printed media is press release, means a policy analysis prepared to be distributed to journalists of the mass media (Sihombing, 2006, p. 6).

Electronic media consist of radio, television and internet. Radio receivers have some advantages such as lightweight, cheap, low power and relaxing usage, without high concentration (Sari, 1993). In the developing countries, the radio very significant role to provide knowledge and inspire the people in finding knowledge and arouse public awareness (Didiugwu, Ekwe, Apeh, \& Odoh, 2014, p. 80). Different from the radio, televisions have stative receivers, high power supply, and require a higher concentration in the usage. Televisions have the high level of effectiveness up to influencing the behaviour and the most preferred by the lower-middle class society (Sari, 1993). Kind of publication can be delivered through television and radio include: feature, talk shows and public services advertisement. "Feature is a creative journalistic product, sometimes subjective, especially intended to entertain and inform audience about an event, situation or everything about life" (Wibowo, 2006, p. 80). A talkshow or interactive dialogue via television or radio is a discussion involving one or several experts as speaker to discuss a specific topic guided by a master of ceremony or a host. A Public Service Advertising (PSA) is a non-com- 
mercial advertising that presents messages to raise public awareness of a problem or to inform about benefit of community service. Meanwhile, the using of internet for communication is in the form of the pages, or better known as websites that can be accessed from all over the world. Website is a collection of pages that contain of institutions information linked to each other (Yuhefizar, Mooduto, \& Hidayat, 2009, p. 2). In addition, the publication format through the Internet can be performed in a from of blog, a social media-based internet applications provided by a certain company to share knowledge and experience to the user of the blog community. The information spread by blogs are proved very effective because of the inducing effect of one to others, especially on the substance of public concern (Hines, 2007, p. 58).

\section{Method}

This research includes evaluation research. The research aims to produce recommendations to improve for the object being evaluated. The process of evaluation studies carried out by finding the distribution of the phenomena and find the relationship between these phenomena, then compared to the objective standards. The method of data collection used in this research was survey method with the vocational high school community as the sample. The data in this study were current status, symptoms or phenomena or states while the research was being held still exist (Dwiningrum, 2013, p. 144).

This research approach was a mixmethod that was more focus on the quantitative method. A quantitative approach is to simplify the way to get stats attitudes and opinions of the large population numbers and the spacious wide of the distribution, Indonesian society. This approach is to obtain the society data related to the publications. Meanwhile, the qualitative approach is to obtain information related to the publication conducted by The Directorate Vocational High School Development. This research was con-ducted through a multi- disciplinary approach includes Public Policy Science, Communication Science, Research and Education.

The population of this study was Indonesian society, the target of the vocational education publication. The sample was taken by using stratafied-cluster sampling technique which consisted of teachers, students and parents. The first step to determine the sample school were based on the region (Java and from outside Java), one district and one town were choosen from every province. Finally, from each district or city, schools (either a private school or a public school) were choosen. This way is a simple way to obtain a sample with the similar condition naturally and socially.

Based on these criteria, two choosen provinces were Banten (to represent provinces in Java) and West Nusa Tenggara (to represent the provices out of Java). The consideration of the selection was that both provinces were meet the average of national parameters in some aspects including geographic, social, economic and demographic that theoretically have an influence on the communication and education. The gross enrollment rate in secondary education level in Banten and West Nusa Tenggara is respectively $72.94 \%$ and $76.68 \%$ in which the average is $74.81 \%$, around the same as the national average: $74.26 \%$ (Pusat Data dan Statistik Pendidikan, 2014). Economically, consumption of food per month per capita respectively is 497.031 and 420.182 rupiah in which the mean both of them: 458.607 rupiah, almost equal to the national average: 439.770 rupiah. The non-food consumption per capita per month is respectively 48,500 rupiah and 39,900 rupiah in which is not much different from the national average (48.900 rupiah). Demographically, the population of Banten and West Nusa Tenggara respectively $10,632,212$ and 4,555,212 people in which the mean: $7,593,712$ people, about to the average of the province population in Indonesian: 7.5 million people. While, the average number of family members per household in Banten and West Nusa Tenggara is respectively 4.10 
and 3.60 in which the mean: 3.85 about to the average of Indonesia: 3.90. Therefore, the selection of those provices is expected to reflect the population of the nationalwide.

The research locations in Banten province were Karya Fajar Vocational High School, in Serang District and The $5^{\text {th }}$ of South Tangerang State Vocational High School. The Karya Fajar Vocational High School represents private and rural areas, while The 5th of South Tangerang State Vocational High School represents suburb areas. Meanwhile, in West Nusa Tenggara set The $1^{\text {st }}$ of Narmada State Vocational High School, in West Lombok representing public school in suburb areas and The AlMadani Vocational High School, Lengkok, East Lombok represents private vocational school in the countryside. 10 students, 10 teachers and 10 parents randomly choosen to represent each school.

Based on the causality relationship, there are two types of variables: independent variables and the dependent variable. The independent variables include: the publications' matterials, the media publication and the audience habits. The dependent variable is the publication effect. The conceptual model of the relationship of these variables shown by Figure 1.

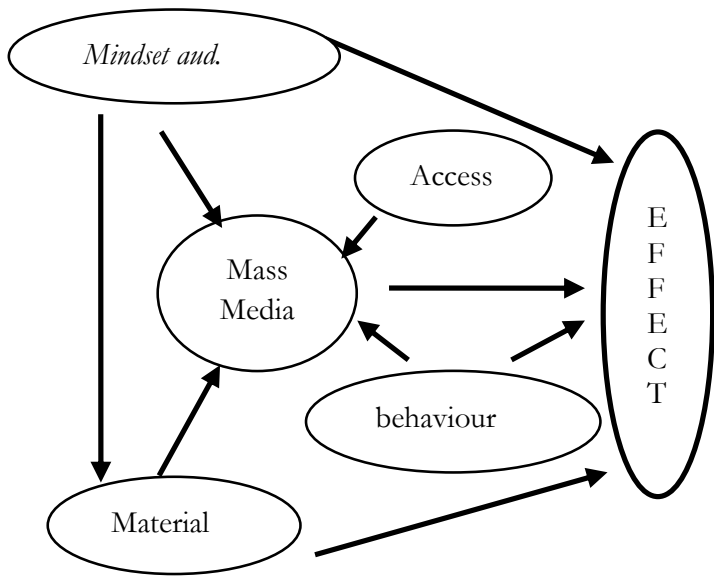

Figure 1. The Relationship Among Variables

The publication material is includes the contents of messages, the messages' formats, and the messages language. Models or speaker as a communicator also included in publication material. The contents of the messages are the core of the information or policy delivered to the public. The formats of the messages mean the publication broadcast technique such as talkshows, public services advertisings and other formats. The message language is the structure of language used. Criteria of the publication materials' appropriateness is the publication material that appeals to the audiences. In terms of the contents, the published policies substances to meet public expectations. The closer the substance to the society needs, the more interesting the content is. The appropriate format is the format that audiences like subjectively, while the proper language is a compelling message and communicative language. The appropriated figure is a figure that has appropriateness or relevance to the message or content delivered. Especially for Internet media, an attractive website is depend on the loading time of the website (the faster is better) and the convenient screen layout.

The role of media publications are to deliver the messages sent by the publisher to the recipient (community). The appropriate media publications are the one that is capable in delivering a message from the communicator to the audience. The condition to allow messages to be received by the people is the connectivity between the public and the media. The media publication is the component of variability because geographically, not all types of media can be accessed at all areas in Indonesia. Printed media are constrained by the transportation to reach remote areas, while television broadcasts is difficult to be used in mountainous areas. Economically, not all residents are connected with all kind of the media because each type of media has its own level of coverage.

The audience habits in the interaction with the mass media varies greatly from one another. Every audience has its own habit of reading newspapers and magazines, listening radio, watching television, and browsing internet. These habits including the duration, frequency, time, and type of 
the favourite media. The audience habits related to the effectiveness of the publication, in which the more frequent the audience access the media, the more likely the audience get the information. Similarly, the longer the audience access the media, the greater chance to receipt the information. Also, the more specific the access time and the favorite media, the easier to determine the time and media to broadcast the publication.

The indicator of the effective policy delivery is the policy at least known by the audience. The publication result is the dependent variable changing follows the independent variables including to: the publications materials, media and audience habits. This variable can be measured through the effect of the audiences' knowledge, emotional effects, attitude and the concrete action.

\section{The Research Results and Discussion}

The Directorate of Vocational High School Development has conducted a number of publications such as "SMK Bisa!", "Senyum SMK", "Go SMK", and "Dunia SMK" broadcasted by radios and televisions. The publications that have been made, need to be evaluated. This evaluation is expected to provide suggestion for the practitioner whether the methods, media and format publication is still relevant to the population. The information enables the publication practisioner to decide weather the publication will be continued or terminated.

\section{The Publication Matter}

The publication material that potentially make the effective publication is the publication material that appeals to audience. Generally, there are two things that can be empowered for the publication material to be interesting material: (1) the importance of the information and (2) the accuracy of the method of the publication. The degree of the interest of the message content is depending on whether the published policies substances meet the public expectations. Thus the criterion the proper message content is the published policies meet public expectations. The closer to meet society needs, the more compelling the message. Based on the survey results the expected information for society is as shown in the Table 1.

Based on the research results the classifications of the perceptions level include the very positive perception: greater than or equal to $83 \%$, the moderate: from $75 \%$ up to $83 \%$ and the negative: lower than $75 \%$. Based on the categorization, the most expected information are the information related to the vocational school function, the student creativities, the competency of graduates each field, the featured major and scholarship programs, the school funds management and the internet utilization. These are become indicator regard to the quality of the vocational high schools and economic affordability that motivate the students to choose the vocational high schools and the main consideration for parents to register their children to the vocational high schools.

Table 1. The Perception to the Content

\begin{tabular}{llccc}
\hline \multirow{2}{*}{ No } & \multicolumn{1}{c}{ The Message Content } & \multicolumn{2}{c}{ Perception } & \multirow{2}{*}{ SD } \\
& & AG & Score & \\
\hline 1. The Vocational Sch. Function & $99 \%$ & $84 \%$ & 0.54 \\
2. The Vocational Sch. Creation & $98 \%$ & $84 \%$ & 0.55 \\
3. The Featured Major & $98 \%$ & $85 \%$ & 0.55 \\
4. The Learning Process & $97 \%$ & $81 \%$ & 0.5 \\
5. Competence of Each Major & $97 \%$ & $85 \%$ & 0.59 \\
6. The Scholarship Program & $97 \%$ & $83 \%$ & 0.57 \\
7. The Use of the Funds & $95 \%$ & $83 \%$ & 0.59 \\
8. The Use of Internet & $95 \%$ & $84 \%$ & 0.63 \\
9. The Prospects of Each Field & $94 \%$ & $81 \%$ & 0.55 \\
10. The Teaching Factory & $93 \%$ & $78 \%$ & 0.53 \\
11. The Referral Vocational School & $93 \%$ & $79 \%$ & 0.52 \\
12. The Real Sector Recognition & $92 \%$ & $82 \%$ & 0.6 \\
13. The Foreign Cooperation & $91 \%$ & $82 \%$ & 0.64 \\
14. The Teknopark & $89 \%$ & $79 \%$ & 0.63 \\
15. The Teacher Improvement & $89 \%$ & $79 \%$ & 0.65 \\
\hline
\end{tabular}

Note:

AG: Agree

SD: Standard Deviation

Based on the 15 items, the reality regarding to the publication content are: (1) the accumulation of the society information needs can be grouped into four categories, 
they are: (1) the services functions, (2) the services qualities, (3) the output qualities and (4) the ease costs. The existence of the categories shown by Oneway Anova Test in Table 2.

Table 2. Anova Test

\begin{tabular}{clcc}
\hline No & $\begin{array}{l}\text { The Information } \\
\text { Categories }\end{array}$ & F & Sig. \\
\hline 1. & The services functions & 0.062 & 0.940 \\
2. & The services qualities & 2.154 & 0.057 \\
3. & The output qualities & 1.284 & 0.279 \\
4. & The ease costs & 0.111 & 0.739 \\
\hline
\end{tabular}

According to the table, the $\mathrm{F}$ test results to the information about the services functions is 0,940 in which is greater than the specified alpha level. This result indicates no significant Table 2. F-Test for Information Categories differences that confirm the existence of the group and the items. Similarly, the informations about the services qualities with significance: 0.057, the informations about the output qualities with significant: 0.279 , and the informations about the ease costs with significant: 0.739 .

To make sure that the existence of the categories, the F test (One Way Anova) were carried out among them. The results $\mathrm{F}$ test showed that there is a clear difference between the informations about the services functions, the services qualities, the output qualities and the ease costs (significancy value: $0,010, \mathrm{~F}=3,860$ ).

Tukey's Post Hoc Tests was conducted to find out the most dominant category. The result of Tukey Post Hoc Test showed that the information of the services functions is the most needed followed by the ease of cost information (see Table 3 ).

The variability of the categories is in line with Hines (2007, p. 58) in her research concerning on the effectiveness of the publications through blogs, especially on the substance of the public's concern. Thus the informations of the services functions and the ease costs became the center of the public attention. The different perception toward categories shown in Figure 2.
Table 3. Comparisons to The Inf. Categories

\begin{tabular}{llll}
\hline $\begin{array}{c}\text { (I) Category } \\
\text { Information }\end{array}$ & $\begin{array}{c}\text { (J) Category } \\
\text { Information }\end{array}$ & $\begin{array}{c}\text { Mean Diff. } \\
\text { (I-J) }\end{array}$ & Sig. \\
\hline 1 & 2 & $.3333^{*}$ & .012 \\
& 3 & .1446 & .544 \\
& 3 & .0333 & .990 \\
& 4 & $-.3333^{*}$ & .012 \\
& 1 & -.1887 & .306 \\
3 & 3 & $-.3000^{*}$ & .029 \\
& 4 & -.1446 & .544 \\
4 & 1 & .1887 & .306 \\
& 2 & -.1113 & .735 \\
& 4 & -.0333 & .990 \\
& 1 & $.3000^{*}$ & .029 \\
& 2 & .1113 & .735 \\
\hline
\end{tabular}

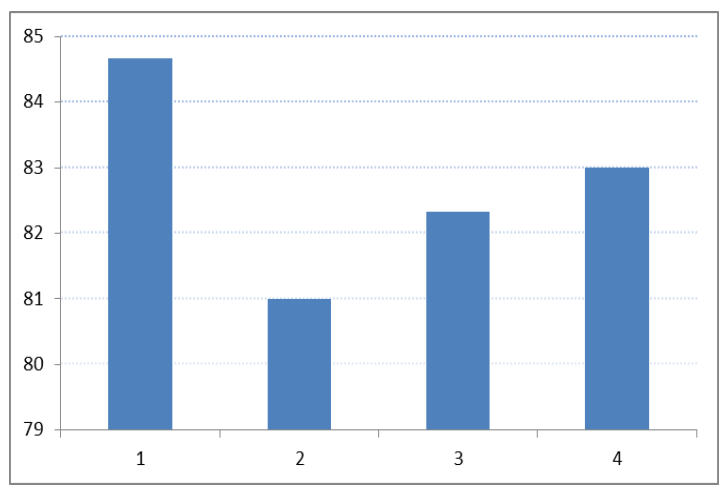

Figure 2. Average (\%) Perception per Category

Note:

1: The services function

2: The services qualities

3: The output quality

4: The ease costs

The accuracy in the publication of the Directorate of Vocational Development is shown by the "SMK Bisa" advertisement, a publication that conveyed the service function of the vocational high schools, in this case to enhance the students abilities. While the function to build entrepreneurship conveyed through advertising and talk show "Go SMK", "SMK Siap Berwirausaha", "SMK cerdas kompeten" and "SMK Bisa Bekerja, Bisa Kuliah".

\section{The Publications Formats}

The interesting formats for the audiences are preferential in nature regarding to 
their own favorite. The formats have a lot of variances, therefore, this study generalizes them into popular format known widely in the community based on the functions. Researching the messages formats is impportant since, in fact, most people access the formats based on their own favorites. This research is able to give recommendations to the Directorate of Vocational High School Development in formatting or preparing the rasionale of publication material. The Preference survey results to mass media formats is as shown in the Table 4.

Table 4. The Perceptions toward Format

\begin{tabular}{lllll}
\hline \multirow{2}{*}{ No } & \multirow{2}{*}{ The Fomrat Media } & \multicolumn{2}{l}{ Perceptions } & SD \\
& & AG & Score & \\
\hline 1. & The TV Knowledge & $96 \%$ & $88 \%$ & 0.61 \\
2. & The News Columns & $88 \%$ & $78 \%$ & 0.60 \\
3. & The Science Column & $88 \%$ & $81 \%$ & 0.69 \\
4. & Radio Knowledge & $87 \%$ & $81 \%$ & 0.70 \\
5. & TV Entertainment & $87 \%$ & $76 \%$ & 0.67 \\
6. & Running teks & $83 \%$ & $75 \%$ & 0.63 \\
7. & The News Radio & $83 \%$ & $77 \%$ & 0.68 \\
8. & Entertainment Clm. & $73 \%$ & $71 \%$ & 0.70 \\
9. & The Internet Blog & $69 \%$ & $70 \%$ & 0.72 \\
10 & The Radio Ent. & $63 \%$ & $68 \%$ & 0.67 \\
\hline
\end{tabular}

Note:

AG: Agree

SD: Standard Deviation

Based on the categorization of perception, this research found the high interested towards science in TV programs. This is related to the motivation to watch TV found by Dahlan (2002, p. 185) in the similiar research field. While the favored programs in the moderate level category are radio news, radio science programs, TV entertainment shows, running text, science rubrics, and news columns on the printed media. While the other types of formats are included in the third category that is less preferred. The format can not be aparted to the media type, so a particular format most appropriate to the particular media. The excellence of knowledge programs in the TV media is not necessarily the format appropriates in the other media. This will be discussed in the further at the interaction effect of formats and media.

The utilization of the TV science programs for the publication of the Directorate of Vocational High School Development have done for 52 times through News magazine during 2011 to 2013. In addition, the science programs have done for 4 times through the TV talkshows in 2010.

\section{The Media Publications}

The media publications role to conduct the message from the communicator to the receiver constrained geographically and economically. This reality causes not all the media types can be accessed in all areas in Indonesia and not all citizens can enjoy the media also.

\section{Coverage Area of Mass Media}

In reality, not all kinds of the media can be accessed in all regions in Indonesia. The printed media is constrained transportation to reach remote areas, while the electronic one are constrained the large area of Indonesia and mountainous topographically so there are so many blind areas that are not covered by electronic signal happen. Ability in reaching large areas may be a consideration in the selection of media for the policy publication of the Directorate of Vocational High School Development for the audiences targets in rural, scattered, outermost and isolated communities. The survey results related to span of media broadcast as shown in the Tabel 5.

Table 5. The Perception to the Media span

\begin{tabular}{lllll}
\hline No & the Media & \multicolumn{2}{c}{ Perception } & SD \\
& \multicolumn{1}{c}{ span } & AG & Skor & \\
\hline 1. & TV & $89 \%$ & $77 \%$ & 0.56 \\
2. & Internet & $79 \%$ & $74 \%$ & 0.75 \\
3. & Radio & $79 \%$ & $73 \%$ & 0.63 \\
4. & Newspaper & $73 \%$ & $72 \%$ & 0.69 \\
5. & Magazine & $65 \%$ & $69 \%$ & 0.65 \\
\hline
\end{tabular}

Note:

AG: Agree

SD: Standard Deviation 
Based on the data, the media that is categorized as "good" is TV while in the "medium" one is the Internet. Radio, newspapers and magazines are categorized into the less category. Radio that had been accepted in a lot of rural areas in Indonesia, apparently has been ratcheted by the new media. The low attitudes of the research respondents regard to the broadcasting span of radio possibility is caused by two things: (1) the decrease of the number of the public interested to access radio and (2) the weakening of radio broadcast industries. These results are consistent with the research result published by AC Neilson on May 21, 2014 which put the TV as the most used media by the public, followed by the Internet, radio, newspapers and magazines.

To prove the superiority of $\mathrm{TV}, \mathrm{t}-$ paired samples test was conducted. The summary results of the t-test is shown by Table 6.

Table 6. The t-test toward Media

\begin{tabular}{lllll}
\hline No & $\begin{array}{l}\text { Gap of Media } \\
\text { Span }\end{array}$ & $\begin{array}{l}\Delta \\
\text { Percep. }\end{array}$ & T & Sign. \\
\hline 1. & TV-Radio & 0.15 & 2.724 & 0.007 \\
2. & TV-Newspaper & 0.18 & 2.619 & 0.01 \\
3. & TV-Magazine & 0.32 & 4.887 & $3.2 \times 10^{-06}$ \\
4. & TV-Internet & 0.92 & 1.240 & 0.217 \\
\hline
\end{tabular}

Note:

$\Delta:$ The Different of Perception Average $\mathrm{t}: \mathrm{t}$ score

Based on the t-test results, there are different coverage among media, in which the TV coverage is the largest one. The coverage of TV is better than radio (sign: 0,007), newspapers (sign: 0.01) and magazines (sign: $3,2 \times 10-06$ ). The order of the media coverage area from the largest is: TV, internet, radio, and magazines respectively. The increase of the using of internet in line with the result of AC Neilson research that found that internet network grows widely under celluler phone support transmissions. Hence, the dominance of TV use in the publication of vocational policy is very appropriate particularly concerning to the policies for the public targeting such as "SMK
Bisa" advertisement with the the number of spots reached 250 spots in 2010 and 623 spots in 2011. However, according to this research, the use of radio in such a large number, 12,650 spots in 2011, should be reduced.

\section{The Availability of The Media Access devices}

The challenges in the publication via mass media is that economically not all people can connect with the media due to the access tools. Each type of media has its own level of expensiveness regarding to the access tools and subscription payment. Only a small number of people can afford the access and subscribe the Media devices. Fortunatelly, watching the TV together with the neighbour socioculturally is still a costume in Indonesia. The publication aspect based on the availability of access devices is very useful in publishing policy matters of the Directorate of Vocational High School Development for the large number of people. The survey results related to the ease in using the media shown by Tabel 7 .

Table 7. The Perception towards Access

\begin{tabular}{lllll}
\hline No & \multicolumn{1}{c}{ Access } & \multicolumn{2}{c}{ Perceive } & SD \\
& Easiness & AG & Score & \\
\hline 1. & Newspaper & $88 \%$ & $70 \%$ & 0.74 \\
2. & Magazine & $88 \%$ & $65 \%$ & 0.65 \\
3. & TV & $83 \%$ & $77 \%$ & 0.66 \\
4. & Internet & $69 \%$ & $76 \%$ & 0.74 \\
5. & Radio & $64 \%$ & $68 \%$ & 0.76 \\
\hline
\end{tabular}

Note:

AG: Agree

SD: Standard Deviation

According to the data, internet and TV are the best in the ease level of access media. The interesting thing is that the radio is widely own by the public in the past, but in present it seems to be replaced by the role of other media. The low perception of respondents about the ease of access to radio is probably caused by two things: (1) the declining of the public interest in accessing radio and (2) production of radio device is weaking as the effect of the declining consumer. 
To prove the existence of the variability regarding to the easiness access of media, t-test paired samples was conducted. The Summary results of the t-test for ease of access shown by Tabel 8. According to the Table 8 , it can be concluded that there is a difference in the ease of accessing the TV media over radio (sign: $2,9 \times 10^{-06}$ ), newspapers (sign: $6,8 \times 10^{-10}$ ) and magazines (sign: $0.001)$. Based on the mean score of perception the sequence from the best media access is TV, internet, magazines, radio, and newspaper. The domination of internet media is in line with the findings of AC neilson that discovered (1) the growth of Internet users with mobile network transmission that grow 5 times higher and (2) the increase of the numbers of public free Wi-Fi areas to access internet. Therefore, the domination of TV in the publication of the Directorate of Vocational High School Development is very reasonable, especially to reach the targeted people in the middle economy class. While the lack of attention to the empowerment of the internet should be stoped.

Table 8. The t-test for the Media Easiness Access

\begin{tabular}{lllll}
\hline No & $\begin{array}{c}\text { Gap Easiness } \\
\text { Access }\end{array}$ & $\begin{array}{c}\Delta \\
\text { Perceip. }\end{array}$ & $\mathrm{t}$ & \multicolumn{1}{c}{ Sign. } \\
\hline 1. & TV-Radio & 0.34 & 4.92 & $2.9 \times 10^{-06}$ \\
2. & TV-newspaper & 0.48 & 6.72 & $6.8 \times 10^{-10}$ \\
3. & TV-Magazine & 0.28 & 3.49 & 0.001 \\
4. & TV-Internet & 0.05 & 0.66 & 0.51 \\
\hline Note: & \\
$\Delta:$ Gap the average perceiption \\
$\mathrm{t}:$ t-test result
\end{tabular}

\section{The Media Excellence}

Every kind of media has it own advantages over the others. The importance to empower of the media excellence in the publication of the Directorate of Vocational High School Development in order to get a strong change effect to the audiences. The characteristics of television with the live images have a power to influence audience behaviour. Similarly, the printed media as a stative kind of information sources in na- ture and the large of the information carrying capacity enable the media to explain complex information perfectly. While radio can easily convey information to the audiences not only for them whom has intention in accessing but also for the unintentional ones. The survey results related to the media excellences shown in the Table 9.

Table 9. The Excellences of the Media

\begin{tabular}{lllll}
\hline No & The Media & \multicolumn{2}{c}{ Perception } & SD \\
& Excellence & AG & Score & \\
\hline 1. & Print Media & $82 \%$ & $74 \%$ & 0.58 \\
2. & Radio & $80 \%$ & $74 \%$ & 0.63 \\
3. & TV & $79 \%$ & $76 \%$ & 0.8 \\
\hline
\end{tabular}

Note:

AG: Agree

SD: Standard Deviation

Based on table 9, that is recognized that the live images of TV have the ability to change the behavior, especially for the middle to lower society class. Currently television images adopt the persuassive technology (the application of computer technology that is designed to influence the behavior) to enhanced this capability. Live images on television are appealing and easy to imitate, therefore it easy to influence the audience beahviour. Publication by TV recommend for the publication that aim to influence audiences' behavior such as in the "SMK Bisa" advertising which shows the dexterity of vocational students in assembling electronic devices. Similarly, "Dunia SMK" present the vocational high schools environments and their achievements to increase audiences' will to study in vocational shcools.

In terms of the broadcasting costs, the printed media is relatively cheaper than others. A Printed media can explain detailly and permanently (the display are not limited by time) so it is most effective to explain and provide detaile information. Thus, the printed media appropriate to send an information that rich of material so the readers are able to read slowly. Although the survey results regarding to the excellence of printed media in the quality of communications 
is only $74 \%$, but $82 \%$ of respondents recognize the benefits of the printed media. These advantages can be used to publish a complex policy such as "Teaching Factory" and "Techno Park". The printed media can be used to explain the purpose and objectives of the policy. The article format can be done in adver-torial so that the informations can be delivered comprehensively such as the advertorial in the Daily Kompas edition of October 29, 2015, entitled "SMK Rujukan Dikembangkan" where the article is clearly outlined the function Referral Vocational School, the requirements, the existing school, the procedure to establish, the supporting facilities and the relationship with the ordinary vocational high schools as well as the government.

Although the effectiveness of television media and printed media is very high, it does not mean that radio cannot be empowered for publications. At least $80 \%$ of the respondents recognize that the radio is very efficient in delivering short and simple information. The cost of publication via radio is much lower than other media and the information is faster to reach the audiences, especially for the middle-lower class audience. The characteristics of the radio receiver are light weight and low power so that the audiences are able to stay connected even when they are doing activities. Therefore, the short information such as the schedule and location of "Gebyar SMK" can be published through radio.

\section{The Intensity of Mass Media Accessing}

The intensity of interaction with mass media regarding to the frequency and duaration of the connectivity of the media everyday is expressed qualitatively in this research. The interactions with the media are the audience efforts to fill their own leisure time and fulfill their need of information. The selection of media are depend on the preferences related to the purposes of interactions and availabilities of the access.

According to table 10, the using of Internet is the highest propensity of audiences where they have often and longer interaction (with the percentage of perception up to $74 \%$ ). On contrary, the radio is experienced to be very weak with the total score of perceiption $59 \%$, lower than the perception of the printed media. Unfortunately, the large number of audiences in using the internet, is not give any advantages to the publication of the Directorate of Vocational High School Development. Moreover, a lot of media formats on the internet can be empowered such as the social media.

Table 10.The Resp. Access Intensity

\begin{tabular}{lllll}
\hline No & The Acc. & \multicolumn{2}{c}{ Perceiption } & SD \\
& Intensity & AG & Score & \\
\hline 1. & Internet & $75 \%$ & $74 \%$ & 0.74 \\
2. & Magazine & $53 \%$ & $64 \%$ & 0.64 \\
3. Newspaper & $48 \%$ & $63 \%$ & 0.63 \\
4. $\quad$ Radio & $40 \%$ & $59 \%$ & 0.59 \\
\hline Note: & & & \\
AG: Agree \\
SD: Standard Deviation
\end{tabular}

Interactions with Mass Media on Weekend

The schedules of people activities on the holiday day are different from the usual. Usually after getting up in the morning, people get ready to work, then working almost a day full, then resting while gathering with their own family, then slept. This habit, on holidays will be changed, in which waking up in the morning slightly late and having vacant time where everyone fill it with various activities. It can change the pattern of the media interaction in the weekly period, because one of the possible activities for a person to fill their spare time is interacting with media such as watching TV and reading newspaper. Watching TV and reading the newspaper on a holiday are to turn over the disruption of access to media during weekdays. The survey results of interaction with mass media on weekend presented by Table 11 .

According to the Table 11, the customs to access TV on Sunday morning are very prominent in the appeal on Saturday in both watching TV and reading newspaper. The perceiption score percentage to access 
TV on Sunday morning is $76 \%$, while on the Saturday is only $55 \%$. The low percentage is because of not all people are off on Saturday, especially the reseach samples that remain work on Saturday. The Sunday morning is the peak of the audiences' accumulation, while the rates of the broadcasts at the time are in the regular fare. Unfortunately, the accumulated audiences on Sunday morning has not been empowered by the Directorate of Vocational High School Development for the publication. Whereas the TV entertainment shows on Sunday morning are proper to be inserted the advertisement like "Senyum SMK Fashion".

Table 11.Respondents Access on Weekend

\begin{tabular}{|c|c|c|c|c|}
\hline \multirow[t]{2}{*}{ No } & \multirow{2}{*}{$\begin{array}{c}\text { Acces Mass Media } \\
\text { on Weekend }\end{array}$} & \multicolumn{2}{|c|}{ Perception } & \multirow{2}{*}{ SD } \\
\hline & & AG & Score & \\
\hline 1. & $\begin{array}{l}\text { Accessing TV on } \\
\text { Sunday morning }\end{array}$ & $76 \%$ & $74 \%$ & 0.73 \\
\hline 2. & $\begin{array}{l}\text { Accessing TV on } \\
\text { Saturday morning }\end{array}$ & $55 \%$ & $65 \%$ & 0.78 \\
\hline 3. & $\begin{array}{l}\text { Read the newspaper } \\
\text { on Saturday morning }\end{array}$ & $48 \%$ & $60 \%$ & 0.73 \\
\hline 4. & $\begin{array}{l}\text { Read the newspaper } \\
\text { on Sundav morning }\end{array}$ & $47 \%$ & $63 \%$ & 0.81 \\
\hline
\end{tabular}

Note:

AG: Agree

SD: Standard Deviation

The survey results regarding to the percentage of the respondent perceiption to read the newspaper to fill their spare time on Sunday morning is $63 \%$. The percentage is higher than the percentage on Saturday morning $(60 \%)$. However, this opportunity is not used for publications of the Directorate of Vocational High School Development. To take advantages of the newspaper readers' accumulation on Sunday, the Directorate have to retain the characteristic of the successful advertising including to the size, graphics design and headlines. In addition, the policy advertisement contain of the content that requires an immediate response. Besides, the publication that aim for professionals, publications can be done through appropriate advertorial section such as education section that provide policy analysis such as "Teknopark".
To examine the differences among the media usage on the different days, ANOVA-two-factor was conducted. The test result showed that there is a difference of the usage of media on Saturdays and Sundays (weekdays and holidays) with significancy level of $3,7 \times 10^{-5}$. Also, there is a clear difference regarding to the usage of each media with a significancy level 0.003 .

\section{Habits Accessing Media on Particular Time}

The pattern of the accumulation of the audiences habits to interact in a particular time bring the concept of the time classification into "primetime" in which the numbers of the audiences are in the peak condition and "regulartime" is where the number of audiences are normal. The habit variability of accessing the media at a particular time presented by Tabel 12 .

Table 12.Habits Access on Particular Time

\begin{tabular}{llccc}
\hline No & \multicolumn{1}{c}{ Accessing Media on } & \multicolumn{2}{c}{ Perception } & \multirow{2}{*}{ SD } \\
& \multicolumn{1}{c}{ Particular Time } & AG & Score & \\
\hline 1. & $\begin{array}{l}\text { Accessing TV on the } \\
\text { Evening }\end{array}$ & $75 \%$ & $71 \%$ & 0.68 \\
2. $\begin{array}{l}\text { Accessing Radio on } \\
\text { the Evening }\end{array}$ & $41 \%$ & $60 \%$ & 0.77 \\
3. $\begin{array}{l}\text { Accessing Radio } \\
\text { While working }\end{array}$ & $38 \%$ & $60 \%$ & 0.79 \\
4. $\begin{array}{l}\text { The Vocational Info. } \\
\text { Accessing when } \\
\text { Admission Sessions }\end{array}$ & $93 \%$ & $80 \%$ & 0.68 \\
\hline $\begin{array}{l}\text { Note: } \\
\text { AG: Agree } \\
\text { SD: Standard Deviation }\end{array}$ & & & \\
\end{tabular}

Based on the table 12, the audiences habits of watching television on the Evening on the score perception is $71 \%$. This finding is fully compliant with the publication showtimes of the Directorate of Vocational High School Development. While the percentage of the score perception related to habits on listening to the radio in the Evening is $60 \%$. The last but very prominent is $80 \%$, the percentage of the score perception related to the information access regard to vocational topic when when the admission sessions. The high percentage is reasonable because such information as the 
reference for making a decision to register to be the vocational high schools students. However, these opportunities are not fully become a reference of the publication the Directorate of Vocational High School Development. Whereas months before the admission of new students are the time in which the school information is needed so the Directorate should done the publication at the time with varieties formats and media. The best publication material regard to the information needed such as vocational education function and waivers of tuition fees with considering the ease access the major audience target evenly. The Islamic Vocational Boarding School in this case also needs to be delivered as a solution for those who want to have the skills without leaving the islamic community culture.

\section{Conclusions}

The accuracy in the Publication of the Directorate Vocational High School Development as follows. The publication materials are including to the policy content and the publication format. The policy content informed the publication appropriate to public need as shown in the advertisement "SMK Bisa" and "Go SMK" in which describe the vocational school functions. Regarding to the publication formats or the broadcast programs, the publication shows the accuracy by using the knowledge or science programs as TV news magazine. Meanwhile, the accuracy in deciding media used for the publication, shown by the most of using TV, in which the media accessible widely in the society in Indonesia. Unfortunately, although the internet used widely currently such as social media, but the benefit has not empowered yet to support the Publication of the Directorate Vocational High School Development. Regard to the publication schedule of the Directorate Vocational High School Development, the most publications time are in the evening, in which appropriate to the time when people is accustomed to watching TV or radio. Meanwhile, the publication schedule has not yet fully referred to the new student enrollment season, in which in the time needed a lot of information regards the schools. Besides, the publication has not taken advantage of the audience accumulation in the TV on the Sunday morning yet, while the time is in the better perception than those in the prime time.

In order to get expected effects in the publication, the Directorate Vocational High School Development as the communicator should take attention on the publication material accuracy including information content regard to kinds of vocational high school services, the broadcast format: the knowledge TV program, the used media: TV and internet, the favorite media as well as the appropriate time including evening, Sunday morning and the new student enrolment season.

\section{References}

Bahar, A. (2008). Meraih passive income dari menulis. Depok: Pena Multi Media.

Brown, B. C. (2006). How to use the internet to advertise, promote, and market your business or web site: with little or no money. Ocala: Atlantic Publishing Group Inc.

Dahlan, S. (2002). Pengujian model nilai harapan kepuasan terbadap penggunaan media. Disertasi. Unpublished. Universitas Indonesia.

Didiugwu, I. F., Ekwe, O. C., Apeh, A. C., \& Odoh, V. O. (2014). Dealing with our apathy through the radio: analysis of the role of FRCN Nnọo Umunwanyi programme in influencing women to participate in politics. New Media and Mass Communication, 32. Retrieved from http://www.iiste.org/Journals/index.p $\mathrm{hp} / \mathrm{NMMC} /$ article/download/18766/ 18692

Dwiningrum, S. I. A. (2013). Metodelogi penelitian pendidikan. Yogyakarta: Universitas Negeri Yogyakarta Press.

Hines, C. (2007). New tactics in public relations: opening dialogue through 
the use of weblogs. The Society for New Commmunication Researchs, II(I), 41-62.

La Torre, G., \& Calzoni, L. (2013).

Smoking Cessation Among Different Settings. In Smoking Prevention and Cessation (pp. 263-289). Boston, MA: Springer US.

https://doi.org/10.1007/978-1-46147046-5_11

Lastariwati, B. (2012). Pentingnya kelas kewirausahaan pada SMK Pariwisata. Jurnal Pendidikan Vokasi, 2(1).

McKinsey Global Institute. (2012). The archipelago economy: unleashing Indonesia's potential.

Medoff, N. J., \& Kaye, B. (2011). Electronic media: then, now, and later (2nd ed.). Waltham: Focal Press.

Pusat Data dan Statistik Pendidikan. (2014). APK/APM PAUD, SD, SMP, SM dan PT 2013/2014 (termasuk Madrasah dan sederajat). Jakarta: Pusat Data dan Statistik Pendidikan, Kementerian Pendidikan dan Kebudayaan.
Sari, E. S. (1993). Audience research: pengantar studi penelitian terbadap pembaca, pendengar. Yogyakarta: Andi Offset.

Sihombing, S. (2006). Panduan publikasi perusahaan: press conference. Jakarta: PT Elex Media Komputindo.

Susanto, M., \& Gusmian, I. (2004). Menimbang ruang menata rupa. Jakarta: Galangpress Group.

Veerkumar, V. (2015). Impact of television advertisement on children's pester power and the purchases made for them in the family. Hamburg: Anchor Academic Publishing.

Wibowo, I. S. W. (2006). Dasar-dasar jurnalistik. Jakarta: LPJA Press.

Yuhefizar, Mooduto, H. A., \& Hidayat, R. (2009). Cara mudah membangun website interaktif menggunakan content managemen system Joomla. Jakarta: PT Elex Media Komputindo. 